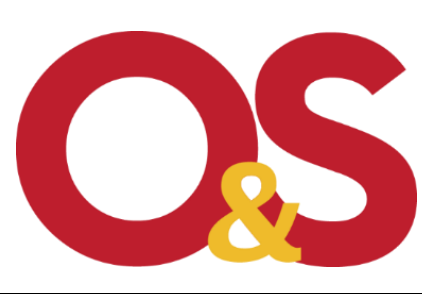

Organizações \& Sociedade Journal 2021, 28(99), 830-859

(C) Authors 2021

DOI 10.1590/1984-92302021v28n9905EN

ISSN 1984-9230

www.revistaoes.ufba.br

NPGA, School of Management

Federal University of Bahia

Associate Editor:

Josiane Oliveira

Received: 07/24/2020

Accepted: 02/11/2021

\title{
The Construction of Knowledge in the Work of a Tattoo Artist: A Look from the Perspective of Aesthetics
}

\author{
Rúbia Goi Becker ${ }^{\mathrm{a}}$ \\ Simone Alves Pacheco de Campos ${ }^{\mathrm{a}}$ \\ Claudia Simone Antonellob \\ ${ }^{a}$ Federal University of Santa Maria, Santa Maria, Brazil \\ ${ }^{\mathrm{b}}$ Federal University of Rio Grande do Sul, Porto Alegre, Brazil
}

\begin{abstract}
The present study analyzes how and what knowledge constitutes the daily work of tattooing in light of the organizational aesthetic approach. For this purpose, the authors explore the theme of knowledge at work by considering the knowledge produced in the daily life of this practice, analyzing the interaction between different knowings, artifacts, and practices. The study used techniques of participant observation and narrative interviews, with data analysis through thematic analysis of narratives. The practice of tattooing consists of six types of knowledge: (a) creation and/or reproduction of the design; (b) doings and sayings related to each practice; (c) manipulation of artifacts; (d) technique; (e) body movement; ( $f$ ) activation of the human senses. Shedding light on the knowledge of the practice of tattooing brings to the focus of organizational studies the importance of the aesthetic dimension, proposing an alternative for the logical-rational understanding of the organizational context.
\end{abstract}


Keywords: knowledge at work; tattooing as a practice; aesthetic approach; sensible knowledge.

\section{Introduction}

Forms of craft work have a nonmanagerial and outsider nature, with the social stigma of being discredited and disqualified (Becker, 2008). The practice of this work involves knowledge in action (Davel, Cavedon, \& Fischer, 2012), which results from the activation of sensible knowledge a good eye, a good ear, and a good nose (Strati, 1999a). This proposition corroborates the findings of Rose (2007), as daily work in this context is seen as irrational, thus devaluing the entire range of everyday knowledge, limiting learning opportunities and the possibilities of instructional connections between different skills and knowledge.

Some studies in the field of administration seek to understand jobs labeled as common and simplistic by society, which sometimes do not require specific training or higher education. Some of these jobs involve work knowledge that does not follow social conventions, such as the activities of bakers and cooks (Figueiredo \& Cavedon, 2015; Soares, 2015), housemaids and cleaners (Caeiro, Neto, \& Guimaraes, 2016; Cardoso, Silva, \& Zimath, 2017), artisanal fishermen (Rodrigues, 2012), airport agents (Bitencourt, 2015), cameramen (Ferrazza, 2015), bioconstruction workers (Camillis, 2016), gravediggers and cemetery workers / morgue and crematorium workers (Batista \& Codo, 2018; Jagannathan, Selvaraj, \& Joseph, 2016; Monteiro, Pereira, Oliveira, Lima, \& Carrieri, 2017; Silva, Souza, Araújo, \& Pinto, 2016), prostitutes and transvestites (Arruda, Moraes, Colling, \& Goldoni, 2017; Carrieri, Souza, \& Aguiar, 2015; Magno, Dourado, \& Silva, 2018), exotic dancers (Mavin \& Grandy, 2013), prison guards (Rudnicki, Schäfer, \& Silva, 2017; Tracy, 2004), street artists (Chiesa, Gois, De Luca, \& Cavedon, 2015), informal parking attendants (Gómez, 2017), street sweepers (Costa, 2008), elderly caregivers (Ostaszkiewicz, O'Connell, \& Dunning, 2016), and tattoo artists (Adams, 2012; DeLuca \& Rocha, 2016; French, Mortensen, \& Timming, 2018; Machado, 2018; Silva \& Saraiva, 2014; Simpson \& Pullen, 2018; Souza, 2015; Wright, 2017).

Some studies relied on organizational aesthetics to understand the constitution of knowledge within the practice of different professions. Among these, studies with the following focuses stand out: the work practices and the learning process of construction workers (Schiavo, 2010); the learning process of professionals who work with custom furniture - assemblers, architects, and salespeople (Oliveira, 2012); the practical learning of nursing technicians (Brock, 2014); the aesthetic experience in the culinary practice of social actors working in restaurant lounges - the chef and her two assistants (Lopes, Souza, \& Ipiranga, 2014); the knowledge and ways of learning in the work of manicures (Gallon, Bitencourt, Viana, \& Antonello, 2016); agroecological farmers in Brazil (Naves \& Reis, 2017); postgraduate students and teachers at a public university (Söllinger \& Antonello, 2020); the knowledge of the work of firefighters involved in a critical event (Gallon, Camillis, Bitencourt, \& Pauli, 2020).

Among the different types of craft work is the tattoo work. Tattoo artists have rarely been the focus of investigation, and when that was the case, the analyses often focused on the content and display of tattooed bodies and not on the tattoo (Glynn, 2017) as a result of knowledge. In this context, studies on tattoos or tattoo artists generally focus on consumers and design (Dyvik \& Welland, 2018; French et al., 2018; Leader, 2015; Patterson, 2018; Souza, 2015; Zestcott, Tompkins, 
Williams, Livesay, \& Chan, 2018). These studies rarely address tattooing as a form of craft work in which workers create and recreate their knowing in practice of their own daily work. Of the few studies on tattoo artists and their profession, those by Deluca (2015), Deluca and Rocha (2016), Machado (2018), and Simpson and Pullen (2018) stand out.

The study of tattooing as a practice introduces a stigmatized artisan craft model in the field of organizational studies. Thus, research addressing the construction of knowing in practice, in light of organizational aesthetics, contributes to the social recognition of tattooing as a form of work (Ferreira, 2012). Society must recognize that as much as the professionals who carry out activities of greater social prestige (considered elitist activities), outsider workers also need knowledge and techniques to carry out their jobs. This understanding allows for reflections that go beyond the classic dualism of the dominant orthodoxy, questioning the actions and the constitutive elements of learning in daily work. The importance of carrying out investigations that address common jobs opens the way for a field of studies hitherto faded amid the mainstream of organizational studies referring to types of work that provide goods and services of style, taste, and well-being (Scott, 2017). Thereby, the present research analyzes how and what knowledge constitutes the daily work of tattooing in light of the organizational aesthetic approach.

By approaching works of this nature, we seek to reveal the character of the social practice of tattooing. This practice consists of habitual ways of doing, which are recognized, negotiated, and supported by embodied knowledge (aesthetic judgment); knowing-in-practice (Gherardi, 2006, 2012); and sociomaterial relationships between organizational actors (subject and artifacts) (Prá, 2019). The present study defines "practice as a 'knowable collective doing', and theorizing activity as a practice situated within a collectivity that supports it socially" (Gherardi \& Strati, 2014, p. XIX). Therefore, "the term 'practice' is a topos that connects 'knowing' with 'doing'; it conveys an image of materiality, fabrication, manual work, craftsmanship" (Gherardi, 2014 p. 6). The study also assumes that knowledge is not only expressed by explanatory or theoretical knowledge, but also arises from a web of knowledge connected and intertwined by artifacts, meanings, spatial arrangements, and incorporated practices (Simpson \& Pullen, 2018).

Conceiving tattooing as a practice means understanding it as a constellation of knowledge present in bodies, inscribed in objects, and articulated in the actions of organizational actors (Gherardi, 2000, 2006). The aesthetic approach helps to overcome the mind-body dichotomy by assuming the senses as a source of knowledge, representing a noncognitive form of knowledge (Antonello, 2011). As a dimension, aspect, and object of organizational research, aesthetics reveals interactions between actions, artifacts (symbolic elements), and sensible knowledge (senses) (Strati, 1992, 1999b, 2007b), which engender knowledge in tattooing.

The present study follows the argument of Strati (2014) that an aesthetic approach to understanding the tacit dimension of organizational knowledge can provide researchers with essential insights into the interpersonal nature of practical knowledge in organizational life. Moreover, Lopes, Ipiranga, and Silva Júnior (2017) emphasize that "understanding the subjective aspects concerning the aesthetic experience through which subjects acquire sensible knowledge is necessary as a way to broaden the understanding of the action of subjects and organizations and its consequences in the context in which they are inserted" (p. 843). Thus, we expect this research to contribute to "opening and expanding the field under study and apprehending everyday common knowledge that logical-rational investigation methods hardly capture" (Lopes et al., 2017, p. 843). 
In addition, this research supports discussions about the construction of knowledge in different professions, in particular in relation to the different knowledge involved in performing so-called common or outsider jobs (Rees, 2016; Rose, 2007).

\section{Aesthetic knowledge}

Organizational aesthetics allows for knowledge renewal in the course of everyday practices through the creation and/or use of artifacts that incorporate knowledge or through the different knowings and experiences of practitioners (Gherardi \& Miele, 2018). In this scope, aesthetics investigates how artifacts (physical or intangible) and subjects (human elements) relate and act in the organizational context, communicating through materiality or immateriality (Strati, 2007b). In the domain of the unspeakable, aesthetics enables what can be felt, observed, described, translated, and disseminated (Ferreira, 2018). Knowledge is accessed through invisible comprehensions in which knowing and acting are only possible due to knowledge obtained and produced by the cognitive logic/faculty directed to intelligible worlds (Strati, 2007b).

It is about understanding the dialectics present in the action and in the relationship between organizational actors, in which materiality and immateriality support the formation of knowing in practice (Corradi, Gherardi, \& Verzelloni, 2008). This close connection between knowing-in-practice and sensible knowledge enables the reconstruction of organizational discourse through aesthetic understanding. This understanding, in turn, is revealed in an I-don't-know-what as a product of a pathos constructed by material/immaterial, lasting /ephemeral artifacts that permeate the practical experience in organizations (Strati, 2007a). As a result of this subjectivity, artifacts enable certain organizational phenomena - which cannot be seen in a material way (learning or knowledge) - to be analyzed interpretively (Strati, 2007b).

Artifacts limit and structure social practices, being subject to modification and employed in different ways by practitioners, establishing a coproduction relationship between knowledge and practice (Gherardi, 2009; Gherardi \& Miele, 2018). The aforementioned concept of knowing-inpractice supports the understanding of how knowledge at work is produced through the interaction between practices (collective, historical, and recursive) and artifacts (Gherardi, 2006, 2009; Nicolini, 2012). This study considers the definition of Rose (2007) for the term knowledge, conceived here from the approximation of the notion of knowing - knowledge is the result of the interdependence between subject, object, and context.

Sensible knowledge enables appreciation and understanding of subjects and artifacts presence or absence, visibility or invisibility, materiality or immateriality-, recognizing the irrational, the emotional, the symbolic, and the aesthetics (Gherardi \& Strati, 2014; Strati, 2007a). Supported by a relational ontology, sociomateriality assumes that social and material aspects of organizations coexist in social practice, understanding that nature and culture are entangled (Gherardi, 2017; Orlikowski, 2007). The elements of a practice - human beings and their bodies, materiality of the work environment, mobilized knowledge, social structures and the relationships that circulate within it - are entangled and enacted in sociomateriality (Gherardi \& Miele, 2018). Thus, by transgressing the boundary between the material and the symbolic, aesthetics breaks the mindbody dichotomy, highlighting the body as an artisan of knowledge. Notwithstanding, the exploration 
of sensible knowledge is only possible during practice, when the body, materiality, and sociomaterial relationships act as an active source of knowledge (Gherardi, 2011).

Sensible knowledge makes it possible to explain how organizational routines are performed through body movements and gestures in which, mediated by the body and its sensations, the individual connects with knowledge (Gherardi, 2012). While mobilizing sensible knowledge, the body produces a conception of taste, refining practices through the bodily ability to feel and like. It thus stages a dialectical movement between individuals and artifacts, which allows communicating sensible experiences (Gherardi, 2013). From taste emanates a situated activity that rests on comprehending and knowing how to appreciate specific performances in practice (Gherardi, 2013). This social orientation generates a prereflective discernment capacity based on sensible experiences, which occurs without questioning the know-how. Taste is the process that socially supports the constitution of aesthetic judgment (corporeal capacity to perceive and feel), with which it is possible to discern whether what is sensed is pleasant or not, whether it corresponds to taste or not. This judgment is produced by practitioners around the performativity of organizational life, supported by the web of interpretations that constitute the aesthetic categories (Strati, 2007b).

If one wants to understand organizations through the analysis of aesthetic categories, one must identify subjective, affective, irrational, and illogical aspects, that is, meanings, collective interactions, theoretical interpretations, and experiences. These aspects reveal knowledge not recognizable by instrumental rationality (Orlikowski, 2002; Strati, 2000, 2007b). Aesthetic categories are expressed by a repertoire of languages that identify the link between practitioner and practice, revealing the aesthetic knowledge experienced by organizational actors (Lopes et al., 2014). One can identify numerous aesthetic categories, however, the literature only addresses few of them to understand organizational life. This fact led Strati (1992) to observe and describe the most frequent aesthetic categories, as shown in Table 1. 
Table 1

Aesthetic categories

\begin{tabular}{ll}
\hline Category & \multicolumn{1}{c}{ Description } \\
\hline Beautiful & Production of pleasant feeling and admiration that does not translate into words. \\
\hline Sacred & $\begin{array}{l}\text { Representations of what cannot be divided. It causes respect and idolatry. The legendary. The } \\
\text { fantastic. The dreamlike. The archetype. That which is not related to organizational rationality, but } \\
\text { rather to the divine and the inviolable. }\end{array}$ \\
\hline Picturesque & $\begin{array}{l}\text { Unusual or bizarre landscapes. A description of something colorful, informal, and emotional, } \\
\text { highlighting the distinction between the aesthetic experience and its evocation. }\end{array}$ \\
\hline Tragic & $\begin{array}{l}\text { The mixed pleasure of suffering and its representation, in which the organizational actor's heroism } \\
\text { lies in challenging what is unknown and threatening. }\end{array}$ \\
\hline Ugly & $\begin{array}{l}\text { Asymmetrical, disproportionate, or poorly formulated. The representation of organizational } \\
\text { alienation, in which mediocrity, bad taste, banality, and artificiality exist. }\end{array}$ \\
\hline Agogical & $\begin{array}{l}\text { Rhythm of activities and organizational phenomena, which can be unpleasant, slow, } \\
\text { interrupted/prolonged, simple, and delicate. }\end{array}$ \\
\hline Comic & $\begin{array}{l}\text { Jokes between coworkers. Sarcasms about the professionalism of women or less skilled people. } \\
\text { Provocative irony. Something that is ugly and smoothly demystified. }\end{array}$ \\
\hline Sublime & $\begin{array}{l}\text { Dignity and nobility of spirit of those who do it. It does not concern an order that is given, but rather } \\
\text { one that may come to be. }\end{array}$ \\
\hline Graceful & $\begin{array}{l}\text { Enjoyment of what is seen and heard, caused by people or organizational artifacts, showing the } \\
\text { refinement of work and people. }\end{array}$ \\
\hline Source: Prepared by the authors.
\end{tabular}

Source: Prepared by the authors.

Separate aesthetic categories are not able to provide a complete understanding of the practice (Strati, 2007b), as each category invites the use of others - multicategoriality - (Ferreira, 2018). The theoretical understanding of everyday life provided by aesthetics unveils a knowledge hitherto not revealed by instrumental rationality (Lopes et al., 2014). It takes place from feeling or understanding for oneself, from situations in which it is difficult explain the experience that was had since it is subjective (Strati, 2007b).

\section{Knowledge at work}

Society has always tended to devalue nonmanagerial forms of work, so-called common and lacking in status and prestige according to social standards (Rose, 2007). Nonmanagerial jobs are inserted in a situated context, accessing sensible, subjective, and informal knowledge produced in and by the act of their daily performance. Antonello and Azevedo (2011) propose that "work is knowing in practice", understanding knowledge as a social activity that does not differentiate between thinking and doing within work practices (p. 92).

The subjects build knowledge at work through dialogue, by associating past experiences with the current context, by seeking information in the literature or with more experienced professionals (Rose, 2007). Consequently, knowledge may either not be perceived or be fully articulated in the discourse (Nicolini, 2012). Even in similar situations, each person tends to act differently, as the bodies are different and the practices that constitute the knowledge were learned in different ways 
- by observation, trial and error, or by instructions received (Rose, 2007). The knowledge of the practice of tattooing cannot be transferred from one person to another through a step-by-step approach, as it is not formalized in scientific terms, being thus difficult to transfer (Strati, 2007b).

Schwartz (2001) explains that there is something in work that escapes the knowledge acquired during training in educational institutions and that can only be achieved through the practice of those who experience work situations, that is, the workers themselves. For Rose (2007), knowledge at work offers an analysis of the worker's physical work and intelligence, enabling reflection on how it is possible to think about it in a clearer and fairer way. Addressing the knowledge of daily work practice allows attention to the study of sociomateriality as a distinctive character of the organization by the body that thinks, judges, acts, and interacts, in addition to being an instrument of organizational production and control (Strati, 2008a). Conceiving the social and the material (bodies, technologies, tools, artifacts, and contexts) as intertwined corroborates the fact that practitioners experience aesthetics through the materiality present in the practices organized by aesthetic categories and embodied in sensible knowledge (Strati, 2008b).

Emphasis on artisanal forms of work, such as tattooing, thus emerges as a rich empirical field. This is especially due to the artisanal nature of tattooing and its brand of outsider activity (Becker, 2008; DeLuca \& Rocha, 2016) attributed by society, which does not recognize it as a profession (Deluca, 2015). As much as professionals who carry out activities of greater social prestige (considered elitist activities), jobs recognized as common require knowledge and techniques. This allows for reflections that go beyond the classic dualism of the dominant orthodoxy, questioning individual actions and the constituent elements of learning in daily work (Rose, 2007).

\section{Methodological procedures}

By entering the interpretive field, the present study analyzes how and what knowledge constitutes the daily work of tattooing in light of the organizational aesthetic approach. This is a basic qualitative study (Merriam, 1998). Data collection involved the application of ethnographic techniques (Brewer, 2000) - participant observation, field diary, and narrative interviews. It took place in three stages: (a) approximation to the field; (b) immersion in the field; (c) distancing from the field for data analysis and construction of the research report (Flores-Pereira \& Cavedon, 2009).

Approximation to the field occurred from April to June 2019 through informal conversations with people who had tattoos and through the monitoring of studios and tattoo artists on social networks (Facebook and Instagram). This process enabled to obtain basic knowledge about the history and trajectory of tattooing in societies, as well as to assimilate elements of culture, organizational aesthetics, language, and the work routine experienced by these professionals. This step was important because the stage of immersion in the field could represent some kind of estrangement due to the lack of previous contact with the universe of work of these professionals.

Immersion in the field (from July to September 2019) involved conducting narrative interviews and observations. The choice of respondents was made by indication of people who had tattoos, resulting in ten narrative interviews with tattoo artists who had been working in this area for more than one year (Table 2). 
Table 2

\section{List of research subjects}

\begin{tabular}{llll}
\hline Name & Age & Time as a tattoo artist & City \\
\hline Querubim & 25 & 18 years & Torovieja, Spain \\
\hline Picasso & 33 & 16 years & Santa Maria (RS), Brazil \\
\hline Rafael & 32 & 13 years & Santa Maria (RS), Brazil \\
\hline Caca & 46 & 28 years & Santa Maria (RS), Brazil \\
\hline Paulista & 40 & 14 years & ljuí (RS), Brazil \\
\hline Tarsila & 44 & 15 years & Frederico Westphalen (RS), Brazil \\
\hline lan & 29 & 2 years & ljuí (RS), Brazil \\
\hline Guga & 36 & 17 years & Santa Maria (RS), Brazil \\
\hline Chico & 42 & 21 years & Santa Maria (RS), Brazil \\
\hline Bibi & 32 & 16 years & Copenhagen, Denmark \\
\hline \multicolumn{2}{c}{ Source: Prepared by the authors. } &
\end{tabular}

The interviews sought to capture personal, situational, and work-related stories of those involved. The interviews relied on a semistructured script, being recorded and transcribed in full. The second step of data collection involved the search and selection of tattoo artists to carry out the observations. From the development of narrative interviews, tattoo artists who had more time in the profession than beginners - professionals with more than three years of experience, as referred by the research subjects - were invited to participate in the observation stage. Five tattoo artists from studios located in the cities of ljuí (RS), Frederico Westphalen (RS), and Santa Maria (RS), Brazil, agreed to have their work routine monitored. Other observations occurred during the $1^{\text {st }}$ Patron Tattoo Fest held in the city of Três Passos (RS), Brazil, in August 2019, and during the experience lived by one of the researchers of being tattooed by one of the research subjects. Observations took place from July to September 2019 (totaling 61 hours) and followed the suggestions of Queiroz, Vall, Souza, and Vieira (2007), as shown in Table 3. The observations and narrative interviews were conducted by the main researcher of the study, with the other authors being involved in the analysis of the collected data. 
Table 3

\section{Script of observations}

\begin{tabular}{|c|c|}
\hline Guiding literature & Focus of observation \\
\hline Organizational aesthetics & Identifying the presence of artifacts in carrying out the practice. \\
\hline \multirow{4}{*}{$\begin{array}{l}\text { Gherardi (2013); Gherardi and Strati } \\
\text { (2014); Strati (1992, 1999a, 2000, } \\
2003,2007 b)\end{array}$} & How do subject-object interactions occur? \\
\hline & How is taste produced? \\
\hline & At what point does aesthetic judgment reveal itself? \\
\hline & Identifying which sensible knowledge is activated in the practice of tattooing. \\
\hline Knowledge at work & How is the practice performed? \\
\hline \multirow{3}{*}{$\begin{array}{l}\text { Gherardi (2000, 2006, 2009, 2011, } \\
\text { 2012, 2013); Gherardi and Nicollini } \\
\text { (2001); Gherardi and Strati (2014); } \\
\text { Nicolini (2012); Strati (2003, 2007a); } \\
\text { Rose (2007) }\end{array}$} & What are the knowledge and actions? \\
\hline & What interactions are present in daily work? \\
\hline & How does knowledge emerge from practice? \\
\hline
\end{tabular}

Source: Prepared by the authors.

From the dataset obtained, we analyzed the narratives by theme (Riessman, 2008). After comings and goings to the field and reading all the material collected, we organized this material according to the theoretical orientation and research objectives. From this interpellation emerged five categories that translate the narrative of respondents. The first step corresponded to the first reading of the material. Then, the reports were organized and the objectives and theoretical issues addressed in the study were reviewed. At the end of this stage, the data were mapped according to emerging themes in the stories of tattoo artists. The significant parts were grouped into themes or research perspectives chosen according to facts related to or happened with the interviewees and concerning the narratives that involve learning the practice of tattooing. Then, analyses were carried out according to the theoretical basis, and a thematic data analysis was developed from the narratives. The analysis is presented through scenes that marked the memory of informants according to their life trajectories. For a better understanding of the narrative, we organized the speech of each informant following a chronological order.

The analysis sought to establish core meanings of work and personal experiences formulated by tattoo artists through the apprehension of common and structuring elements of the experiences narrated by them. Five themes naturally emerged in the analysis of data from the narratives, in the order shown in Table 4. In other words, the subjects' narratives in relation to the practice of tattooing followed the thematic order given by the research subjects themselves. This enabled grouping the significant parts of the stories in light of the remarkable events in the construction of knowing in practice of tattooing: (a) the awakening to the taste for the practice of drawing, which, in general, portrays the first approximation of the tattoo practitioner to the art, being the act of drawing itself understood as the first step in learning to tattoo, as here the individual produces drawing-related knowledge; (b) the initial experience with tattooing, that is, the moment when the individual practices tattooing for the first time, with no intention of becoming a professional; (c) the emergence of the practitioner as an apprentice of his practice - the individual becomes a practitioner 
in training while seeking to become a tattoo artist; (d) the professionalization of the practitioner who is already aware of his/her practice, then proceeding to refine it; (e) becoming able to communicate and share sensible experiences about their professional practice, going from apprentice to master so that, already being knowledgeable, they can transmit their experiences, starting to define the taste for the practice - after being able to resignify it, they legitimize their practice and can share their knowledge with other practitioners.

Upon entering the narratives and through immersion in the field, we sought to identify indicative signs of the presence of aesthetic categories (Strati, 2007b) (beautiful, sacred, picturesque, tragic, ugly, agogical, comic, sublime, and graceful) according to the presence of its constituent elements in the tattoo artists' narratives. The aim was to understand the formation of the individual's aesthetic judgment during the construction of their knowledge. After defining the thematic categories, we analyzed the narratives of the research subjects aiming to recognize how they oriented themselves during practice. This made it possible to detect the aesthetic categories responsible for the construction of knowledge about the practice of tattooing. The identification of these themes, later guided by the theoretical basis, is explained in Table 4.

\section{Table 4}

\section{Emerging themes of narratives}

\begin{tabular}{|c|c|c|}
\hline Theme & Description & Theoretical basis \\
\hline Taste for drawing & $\begin{array}{l}\text { Construction of knowledge that preceded the practice of } \\
\text { tattooing. }\end{array}$ & $\begin{array}{l}\text { Gherardi }(2012,2013) \text {; } \\
\text { Gherardi and Strati (2014); } \\
\text { Strati (2007b). }\end{array}$ \\
\hline $\begin{array}{l}\text { Experiencing } \\
\text { tattooing }\end{array}$ & $\begin{array}{l}\text { First experience with the practice of tattooing, elucidating the } \\
\text { moment when the individual discovers himself/herself as a } \\
\text { practitioner. }\end{array}$ & $\begin{array}{l}\text { Gherardi (2006, 2013); } \\
\text { Gherardi and Nicolini (2001); } \\
\text { Nicolini (2012); Strati } \\
\text { (2007b). }\end{array}$ \\
\hline $\begin{array}{l}\text { Becoming a tattoo } \\
\text { artist }\end{array}$ & $\begin{array}{l}\text { Knowledge is built on the relationships that occur between } \\
\text { subjects and between subjects and objects. It is produced by } \\
\text { practice and based on it, through a social, human, material, } \\
\text { and aesthetic process. }\end{array}$ & $\begin{array}{l}\text { Gherardi }(2006,2009) \text {; } \\
\text { Gherardi and Miele (2018); } \\
\text { Strati (2007b). }\end{array}$ \\
\hline Professionalization & $\begin{array}{l}\text { The practice of tattooing becomes refined by recombining } \\
\text { behaviors and elements (material and discursive) and by the } \\
\text { interaction between artifacts and practitioners, establishing an } \\
\text { aesthetic judgment of right and wrong as well as imposing } \\
\text { restrictions. }\end{array}$ & $\begin{array}{l}\text { Gherardi (2012, 2013); } \\
\text { Gherardi and Strati (2014); } \\
\text { Gherardi and Nicolini (2001); } \\
\text { Strati (2007b). }\end{array}$ \\
\hline $\begin{array}{l}\text { From tattoo artist } \\
\text { to tattoo artist }\end{array}$ & $\begin{array}{l}\text { Communication of sensible experiences and sharing of ways } \\
\text { of practicing institutionalized by norms of good practice. }\end{array}$ & $\begin{array}{l}\text { Gherardi (2012); Gherardi } \\
\text { and Strati }(2014) ; \text { Strati } \\
(1992,1996,2003,2007 \mathrm{~b}) \text {. }\end{array}$ \\
\hline
\end{tabular}

In the field of ethical considerations, this study meets the recommendations of the Research Ethics Committee (CEP) of the Federal University of Santa Maria, Rio Grande do Sul State, Brazil, being recognized by the Research Ethics Committee (Conep) - CAAE 14524719.4.0000.5346 according to its registration in Plataforma Brasil. 


\section{Tattooing: narrative of the learning of this practice}

This section provides understandings about the constitution of knowing in practice of tattooing through the presentation of narratives in five themes: (a) the taste for drawing; (b) experiencing tattooing; (c) becoming a tattoo artist; (d) professionalization; (e) from tattoo artist to tattoo artist.

\section{The taste for drawing: awakening to the practice of tattooing}

In the construction of drawing knowledge, for one to learn to tattoo, one immerses oneself in the intersubjective universe of everyday life. This has to do with the close interconnection of reified human feeling and thingness, as conceived by Strati (2007b). In this sense, one does so by understanding that one deals with a sensibility that is one's own, which allows to define drawing as the initial repertoire of knowledge. In this regard, the design is:

The first thing... it's much harder for you to learn to tattoo without knowing how to draw, because. . (if something goes wrong) you don't know if it's the material or if it's you. If you don't know how to make a straight line, how do you want to make a straight tattoo? (Picasso, 2019)

This finding elucidates the idea expressed in the understanding of Gherardi and Strati (2014) about the cocreation between the knowing subject and the known object, between knowing and comprehending, between the practice and the practitioner, in which taste for drawing and the practice of tattooing occur as a reciprocal constitution and a habitual act. Practitioners become aware of themselves and their practice during daily performance. In other words, the dialogues between the practitioner and the knowledge process take place in the doing. Chico's narrative evidences this situation: "I have always drew. . . I have improved my technique in drawing. It was very informal. No course. . I learned on a daily basis". Rose (2007) states that one acquires the repertoire of knowledge through training, experience, and observation. The author portrays knowledge in the work of hairdressers, which, just like in the work of tattoo artists, is produced intrinsically to the individual. Drawing knowledge is unique and nontransferable, expressed by creative knowledge of image production and technical knowledge of image reproduction.

Creative knowledge comes from the greater facility for drawing, correlating with the artistic nature, as lan explains: "It's that person ... who manages to get the drawing he/she makes. . and transfer to the skin. . It is a person who has a history in art. . It's not the one who only applies the paint". This finding is consistent with the understanding of Gherardi and Strati (2014) when inferring that knowledge is accessed through the senses, therefore belonging to the complex network of representations that cannot be anticipated and scientifically explained. Drawing also involves technical knowledge that is developed and refined through training, experiences, and senses (Gherardi \& Strati). Guga reveals: "My drawing is more like a technical drawing. I do what I see. . . The artistic design. . . depends a lot on inspiration. . . It comes from the mind. . The hand flows".

In the practice of tattooing, knowledge is produced in the interaction between senses (looking or reproducing; imagining or creating) and artifacts concerning the practice. According to 
Corradi et al. (2008), this situation expresses the relationships between actors and the relationships of these actors with technologies, methods, and rules. Such association can be observed as:

A language, like a drawing would be, like a painting would be. . . A given technique in which one develops the ideas one wants to show... The paper is common to us. The canvas is common to us. But skin is not that common. (Picasso, 2019)

By dealing with the artifacts paper, canvas, and skin, Picasso's report evokes the aesthetic experience referring to the aesthetic category of the picturesque. The report conceives tattooing on the skin as unusual in the practice of drawing, indicating, according to Strati (2007b), an unusual landscape. Sensitive representations are unintelligible by rational analytical procedures, as the knowledge inherent to the taste for practice is only accessed by the perceptive faculties of aesthetic judgment (Strati, 2007b). The aesthetic understanding of the practice of drawing is noticeable when the practitioner manages to transpose the knowledge of drawing from the paper to the skin:

There's the guy who draws. . and the tattoo work is wonderful. And there are people who reach the skin and. . it won't happen, you know? Within the tattoo world there is a lot of categories. . . Ways of doing. . Each tattoo artist tries to find the best way. (Guga, 2019)

Knowledge in the practice of drawing, as a matter of taste, involves the perception and interpretation produced by aesthetic knowledge, relying on experiences, subjectivities, and learnings memorized by practitioners (Gherardi, 2013). Paulista highlights: "I used to look and do something similar... Then I started drawing, making the decal on paper. I used to do that. I would search for the lights. I would paint... By drawing I started to see how it looks like... The step by step". From the design characteristics and from previously stored professional experiences, tattoo artists have an idea of how the tattoo should be. Thus, knowledge in the practice of drawing has to do with a process that is mentally idealized and assimilated, as well as with a physical and aesthetic dexterity of the artifact (paper and pencil, tablet, and pen), as mentioned by Davel et al. (2012).

The know-how of the practice of tattooing depends on the conversion of knowledge of creation and reproduction into drawing. In this regard, Caca mentions: "Me... I used to draw by hand... There was no printer. There was no computer... I had to get a lot of drawings... One has to have a lot of time and training". This finding correlates with the spheres of materiality, fabrication, manual work, and craftsmanship. It elucidates the knowledge produced by situated practices of production and reproduction, anchored in corporeality and in artifacts of representation and mobilization (Gherardi \& Strati, 2014). Knowledge in the practice of drawing thus results from construction, maintenance, and reconstruction of the intelligibility of everyday practices, supported by a sociomaterial arrangement - people, artifacts, and objects - and expressed in the basic actions of doing and knowing.

There is no fixed order in which knowledge is embodied and socially apprehended. It occurs in the interaction of shared experiences between people and bodies, reflecting a knowing how to feel (skin texture) and a doing (handling equipment or artifacts). The knowledge involved in drawing creation acts as a link between the practitioner and his/her practice, revealing, in front of other 
professionals, his/her identity as a practitioner. It is the effect of the collective formation of taste in the process of constructing the aesthetic judgments that support the practice (Gherardi, 2013).

\section{Experiencing tattooing: from paper to skin}

The first contact with the practice of tattooing is marked by provisional knowledge, referred to as the tacit knowledge of tattoo artists. This knowledge is guided by aesthetic categories that will sustain an aesthetic judgment, transposing a previously unestablished knowledge. According to Orlikowski (2002), it is built and improved during practice, in a self-taught and amateur way. Guga recalls: "I made my first tattoo machine so I could tattoo... Of course the tattoos sucked. It got really bad. They got too ugly". This narrative signals the aesthetic category of the ugly, which emphasizes everything that is horrible, eccentric, or unpleasant (Strati, 2007b).

During tattoo experimentation, knowledge comes from socialization processes, in which learning and socializing coexist, that is, learning is always a social and relational achievement (Gherardi \& Nicolini, 2001). According to Guga, one needs to experience it in oneself, to feel the practice. This is a point at which the category of the picturesque (Strati, 2007b) emerges in the narratives through the evocation of the aesthetic experience: "The first time I manipulated a tattoo machine, I did it in myself to know the depth of the needle".

By elucidating the aesthetic experience, Guga's narrative reveals the presence of the aesthetic category of the picturesque (Strati, 2007b). lan highlights the same context when describing the emotions provoked when making his first tattoo: "I made a design that I thought was cool... It was in the leg... I was very nervous. I shivered while doing the tattoo. It was a very bad experience". Knowledge is contained in bodies, inscribed in objects, and articulated in the actions of organizational actors (Gherardi, 2006). However, it is not always explicit or fully articulated in the discourse (Nicolini, 2012). As for the subject-object interaction, Caca's narrative pays attention to the aesthetic category of the agogical (Strati, 2007b) with regard to the rhythm of actions marked by the strokes of the needle. This was due to the use of an improvised and slow machine: "The first was a more primitive machine... made with a little motor from a tape player... The beat was very slow. It didn't have those beats like 'zeeee', you know? It was a beat like tap, tap, tap, tap."

Knowings are permeated by singularity, which is why it cannot be obtained by industrial logic; it rescues and reproduces invisible and indivisible knowledge. Querubim, for example, recognizes that although he learned to tattoo from his father, the doing is not the same: "Someone can do something like someone else, but the work... it's different because one has a style, a way of tattooing... Even if... one does the same tattoo, it will not be the same". It is the understanding that the paths followed by practitioners may vary from tattoo artist to tattoo artist. According to Rose (2007), the choices and paths adopted differ, as every practitioner will have to resort to a repertoire of procedures (norms that make the practice legitimate) to perform the practice. Tarsila's narrative illustrates this understanding. This respondent sought knowledge with a professional tattoo artist and reported the following: "He started teaching me how to weld a needle... He was giving me the entire machine procedure, how it worked..., asepsis, hygiene, safety, and everything".

In developing their art, creativity, and technique, practitioners mobilize knowledge through a construction that occurs in everyday life and allows knowledge to be perpetuated, modified (Antonello \& Azevedo, 2011; Nicolini, 2012), or shared through sensible experiences (Gherardi, 
2013). In order to apprehend the feeling in its being-in-use (Strati, 2007b), the aesthetic experience is lived and relived during practice through images, comparisons, metaphors, and symbols, conveying an intuitive understanding, as evidenced in the following excerpt:

My childhood was. . . wanting to do what he was doing. I imitated what he was doing. I thought: 'This is it. So you have to do this'. . . He used to teach me little by little. But he never taught me for real. It was always more of a me looking, observing, and asking. (Querubim, 2019)

The practice of tattooing portrays a tangle of specific knowledge that translates into actions that are not expressed in (technical) manuals, but rather arise from intersubjectivity (sensible knowledge). This knowledge reflects a dialectical interaction of transforming something immaterial (drawing) into something material (tattoo), dwelling in and self-fulfilling through the transformed matter. Knowledge is always embedded in a concrete situation (enacted by organized ways of doing) or, according to Gherardi and Strati (2014), in ongoing practices (seeing, saying, and doing) that make knowledge observable.

Becoming a tattoo artist: interaction between practices, knowings, artifacts, and sensible knowledge

Practitioners start to reframe and refine practice during its production and reproduction. For this they rely on observation and aesthetic experience as the main sources of construction of knowledge, especially regarding welding needles, sterilizing materials, assembling the equipment, handling the machine against the skin when drawing, the depth at which needles should be inserted, how to dilute and apply the pigment, and how to trace and shade the skin (field diary). For many practitioners who began their trajectory in tattooing in a period in which access to the internet and technological support were limited, the construction of knowledge evoked the aesthetic category of the picturesque:

Directly on the skin... There was no artificial skin. If one wanted (something like that), one would go to the butcher shop and get pork skin, because the texture is more similar to ours. . I never got to train. It was always in me or someone else. (Guga, 2019)

Schwartz (2001) corroborates this discussion by considering that the ability to perform a task is acquired through experience, invested in the bodyself by activity in historical situations. Often not even the worker himself/herself realizes that he/she used knowledge that was not provided for in the protocol or the norms, as it had been hidden in its bodyself. Artifacts acquire functionality, utility, and practical application, but only act with intent with the practitioner: " $A$ machine is practically a heavy pen... What is different is how you are going to draw" (Caca, 2019). The tattoo artist's sensitivity in handling the machine reveals the aesthetics present in objects and feelings, whether for those who use it, speak, or interact. This reaffirms the conception of Strati (1992) that materiality surpasses organizational knowledge, as it is embodied in sensible knowledge. 
Knowings derive from sensible knowledge produced both in the lived context - in which practice is performed amidst the interaction between practitioners, artifacts, and practices recognized in the field - and in the aesthetics created, which is reconstructed or destroyed in everyday organizational negotiations (Strati, 2007b). For lan, knowledge manifests itself in the interaction with artifacts: "The machines I'm used to are like part of my arm. I already know the weight. I already know how it goes". The intertwining between sensitivity and subjectivity enables the abductive and/or intuitive apprehension of reality so that, when tattooing, the subject emphasizes the knowledge arising from his/her aesthetic experience, which results from previously unformulated intuition (Strati, 2007b).

For Rose (2007), the more experienced the practitioner is in his/her practice, the more natural his/her ability will be. This explains the relationship between the tattoo artist and his/her machine and the pathos of the sensible. For Strati (2007b), it is a product of nonmental knowledge and nonintellectual knowledge, which are empirically indescribable. This understanding is represented by the following narrative:

The coil machine, only from its noise one could recognize if it was regulated. . Setting your hand height. . . Setting the machine power. . . 'When do you know it's okay?' I can't tell you. It's the practice. (Rafael, 2019)

Rafael's narrative unveils what Strati (2007b) calls I-don't-know-what while the tattoo artist moves during practice, handles the machine, and adjusts the power of the needle stroke on the skin being tattooed, in an automatic and instinctive performance of knowledge evocation. Another relevant point concerns the fact that there is no action planning, that is, the tattoo artist does not establish a step-by-step of his/her doing prior to the moment of action. According to Rose (2007), this also occurs in the work of hairdressers. Even if the tattoo artist defines in advance which artifacts will be needed (such as machines, needles, inks, and paper towels), the knowledge activated and the paths taken by the professional will only be unraveled when he/she touches the skin and inserts the needle in it, making the first line on the decal (mould drawing). Then, tattooing progresses while he/she observes and feels how the skin reacts, leading him/her to reflect and act at the same time, based on the performativity of the practice:

I make the first line. . lightly and at a medium speed. . I see if it got too thick or too thin. Then I already know. . . the speed to use. . I get to feel. . . the way. . . that better fits the vibration of the skin. (Ian, 2019)

Through the activation of sensible knowledge, the practitioner accumulates in the body the ability to act in the world and to do it individually through practical activity, anchored in materiality and discursiveness (Gherardi, 2012). The aesthetic judgment of tattoo artists begins to form when they begin to assimilate the knowledge constituted in their daily work and transform it into their particular capacity to judge. The presence of the agogical aesthetic category, which deals with the importance of the pace of activities for conducting processes and the workflow (Strati, 2007b), can be recognized in Guga's narrative: 
If you tattoo every day, your hand becomes more and more in tune. . It's automatic, you know? By contacting the machine with the skin, you will feel if the skin will refuse or accept it. . . It has to be hyperpigmented. So you have to. . . put more pressure on the machine, more strength in the hand. (Guga, 2019)

The materiality implied in the practice demands that the practitioner develop deep knowledge of the manipulation of artifacts, learning how to adapt, create, and recreate their practice. Therefore, knowledge is interwoven into social structures and the emotional and affective relationships that circulate within them, essentially mental and sensory (Gherardi \& Miele, 2018). Paulista believes that the support of the artifact contributes to building and revealing taste in practice: "If I take and put the image on the iPad and enlarge it, I achieve a much better result than by looking it on paper. . . It gets perfect as I want it to be".

The result of the recursiveness of the practice (Gherardi, 2006, 2009) impacts the execution of a good job, which correlates closely with the artifacts that permeate the process of making and with the technical (procedures) and material evolution (technology of artifacts), contributing to that the practitioner hone his/her sensible skills in doing. Chico relates: "For a long time, I worked the wrong way. . . I couldn't do it. It's just that I had to learn it by myself. . . I used to do experiments. Sometimes I would talk to someone or look in a magazine". Although some knowings are considered formal, such as biosafety - due to its regulatory nature -, the transmission of knowledge relies on practices, which are shaped in the course of action.

The knowings involved in each stage of tattooing can be partly passed on from tattoo artist to tattoo artist. However, these artists are limited to knowing how to do it with their hands according to techniques that guide this process, but that do not define what to do. By practicing, the practitioner produces and reproduces actions. Good practices become habits that are sustained. A normative orientation is maintained and goals are achieved (Gherardi, 2009).

\section{Professionalization: refining the practice}

The professionalization of the practice corresponds to the stage in which the tattoo artist apprehends a professional view, a perceptive judgment that not only synthesizes the sensation experienced but also expresses whether the practice was well done or poorly done, that is, whether it represents the social standard of the community (Gherardi, 2013; Strati, 2007b). Tarsila reveals: "Between. . . the beautiful and the ugly. . . there is no right or wrong, because we are talking about an artistic work. . . Now, when we talk about quality work, it is. . a job well done or not". The category of the beautiful that guides the practice of tattooing is expressed by a feeling of admiration, which does not translate into words. In this context, the bad practice consists of the category of the ugly, demarcating what is unpleasant, filthy, and disgusting in the organization (Strati, 2007b). Equally highlighted, as emphasized by Rose (2007), is the feeling of admiration for the well-done practice, which awakens the feeling of pride and admiration for the work done.

The professional view is expressed by the taste that allows the practice to be performed according to the definitions of a well-done practice, that is, according to institutionalized rules expressed by the aesthetic category of the beautiful, which distinguishes a well-done work from a 
poor work (Strati, 2007b). The practice built daily by the practitioner, without either preliminary training or someone who can provide this knowledge, reveals the idiosyncrasy of aesthetics since it enables the unfolding of knowledge from rationally unknown dimensions. This understanding is revealed in the following narrative:

The machine does $50 \%$. The other 50\%. . it's from the tattoo artist's hand. . I feel when I'm hurting someone. . You won't tattoo someone's back the same way. . . with the same movement, the same depth, or the same speed. . than on the wrist. (Paulista, 2019)

In interaction, subjects and artifacts build themselves and a certain way of looking at the world that reverberates not only in the constitution of knowledge, but also in the practical production of tattoo artists. This production can be both prereflective and dependent on subliminal assumptions as well as on shared knowledge to obtain meaning (Gherardi \& Nicolini, 2001). In the case of tattooing, the registration of the sensible experience results from a set of sensations activated by the aesthetic judgment present in the skin texture, in the sound of the machine (adjustment), and in the insightful look at the work performed, as seen in Querubim speech: "You have to adapt yourself at the moment. You will notice when it is not working. It's like playing a guitar. You will notice that the guitar is not in tune. It's like fixing the machine".

The evolution of practices, standards, and norms occurs through the continuous refinement of institutionalized practices (Gherardi, 2012). Moreover, the recursiveness of the practice results from its sharing among practitioners, enabling the construction of guiding assumptions about good practice (Gherardi, 2012; Gherardi \& Strati, 2014), which correlates with the aesthetic categories of the beautiful and the ugly (Strati, 2007b). Caca explains: "A professional tattoo artist will see the mistakes in detail. . . That's the difference of the person who knows".

The diversity of knowings arising from the aesthetics present in the practice of tattooing (looking, feeling, listening, judging) allows for ample freedom of choice regarding what to do. This context involves the combination of knowings (drawing, assembling the material, handling artifacts, preparing the skin to receive the tattoo, and mastering application techniques). Chico's narrative reinforces this aspect:

I use shortcuts when placing the drawing, when drawing, when painting, while many people, for not having this knowledge. . . end up confused, doing things in the most timeconsuming way. ... It is the advantage of people who have tattooed for many years. (Chico, 2019)

The direct connection between thinking and feeling, based on the sensory faculties of individuals and their bodies, allows the tattoo artist to experience and understand the practice without needing a previous rational explanation. This professional thus bases his/her work on a nonmental, nonintellectual, empirically indescribable knowledge that relies on the participation of individuals in the construction of the social aspect (Strati, 2007b). Tattoo artists seek to discover ways of knowing that may benefit them in their practice, considering their sensory faculties and their relationship with the artifacts. By generating sensible experiences, these factors allow 
practitioners to store, in their thoughts, feelings and reason that involve the everyday experience, producing learning. In Guga's words:

A person arrives wanting to do it. . . A person you've never seen in your life. . The person prints a photo and schedules the tattoo for two months. . You will look at that picture every day. . Y You will see things you didn't see. . Your eye must become addicted to that design. (Guga, 2019)

Thus, the choice of artifacts used in carrying out the practice is an automatic decision guided by the senses and the experience accumulated through practical experience. It correlates with doing and knowing. This context emphasizes the contribution of information and communication technologies, recognized by Gherardi (2012) as a nonhuman facilitating element. Bibi exposes the role of artifacts both as facilitators of practice and towards greater safety in doing: "We control it by foot. It's like a sewing machine. . One turns the machine on and off by foot. . If I take my foot off the power source, the needle goes in automatically". The development of knowledge is not detached from work practices, as the context influences the action and acquired knowledge (Gherardi, 2012).

\section{From tattoo artist to tattoo artist: communicating experiences}

The way in which knowings are activated and constructed during its performance derives from the experience lived by people through their actions. It is thus a singular and unique process that results from the aesthetic understanding of the practice, as sensible knowledge is intrinsic to each practitioner. This is what this excerpt from an interview reveals:

I can't pass my knowledge on to you. I can explain you my technique. The way I hold the machine. The way I handle the machine. The way I make the mold. The rest is up to you. (Rafael, 2019)

Knowledge is not the result of indicative data, but rather is produced by the imaginative and intuitive capacity that each performer puts into practice, becoming a lived experience (Strati, 1992, 2007b). In addition to the practical knowledge regarding the handling of artifacts and the way to carry out the practices of the tattoo craft - touch and recognition of the type of canvas (skin) -, there is a concern to know the right way to practice.

Firstly, choose the style. Study. . . Draw. . . Then, to learn how to tattoo, talk to someone who is willing to teach. Go and practice on artificial skin. Then choose the machine that makes you feel comfortable; that will adapt to your hand; that you will be able to touch, hold, balance the weight. Go and choose the best machine for you; the best pigment; the best needle. But everything related to that specific job. . . It's like brushes in painting. . . There are brushes with a very soft bristle; brushes with a thicker bristle. In the tattoo universe. . our needles are our brushes. (Guga, 2019) 
This evidences the intertwining between the tattoo artist and the sociomaterial means in their daily lives and in the constitution of their knowledge and what makes up good practice, i.e., the beautiful. Using Rose's (2007) metaphor when analyzing the work of hairdressers (they think with the scissors in their hands), one can say that the tattoo artist thinks with the needle, making it an extension of himself/herself to the skin to be tattooed. In a perfect symphony between practice, the body, and material artifacts, knowledge is produced and reproduced, resulting in a job well done. The constitution of knowledge is, therefore, intertwined with the construction of the aesthetic judgment of the professional.

The production of taste shapes work practices and reframes them through negotiation and reflection, which suspend the flow of action to intervene and experience the practice and express an aesthetic judgment about it. This judgment becomes known through the five human senses: sight, smell, hearing, taste, and touch (Strati, 2003). Learning occurs through interactions between practitioners and the world, and contributes to building different practices, as seen in this speech:

I've always liked to do a kind of application that is called layering. . . I developed knowledge on this technique by myself. But I wasn't sure I was doing it right. . . until I got in touch with Max... He came to give a three-day workshop. Then I got there and, to my surprise, it was the technique he uses... When a professional comes and tells you 'black and shadow you do like this'.. . When someone can explain all this to you. . You will get the machine and 'alright', and then you managed to do it. (Chico, 2019)

Telling and listening to stories is not a secondary activity in knowledge sharing. It contributes decisively to form a collective memory that stores and transmits what was learned in the field and constitutes a normative infrastructure which supports the performance of work practices (Gherardi, 2012). Practices are constantly refined by the process of taste formation, which works both as a feeling of the perfectible and in repetition as a tension towards a perfection never achieved. This premise is represented in the following excerpt:

There is no right way to tattoo. There is the wrong way, since a tattoo artist will use. . a machine on one voltage and another tattoo artist will use it on another. . voltage. One tattoo artist uses a millimeter of needle sticking out of the machine. Another one uses three millimeters. . Each one will adapt in their own way. (Chico, 2019)

These findings highlight the statement of Rose (2007) that subjects build knowledge at work through dialogue, by associating past experiences with the current context, and by seeking information in the literature or even with more experienced professionals. In this process, the subject produces new unique knowledge based on acquired knowledge. This allows him/her to think, transform, and feel the practice, building knowledge that is in constant evolution and enables him/her to mold his/her practice.

Sensible knowledge, which does not respond to objective and universal criteria and which each person possesses in an entirely personal way, is constantly negotiated in a process whose result is by no means certain, given the different sensitivities of organizational actors (Strati, 2007b). 
Among the types of knowledge needed to learn to tattoo, Guga mentions the importance of knowing how to handle the artifacts that constitute the practice: "First, study the style. . Then, look for a professional who can teach you and start practicing on artificial skin. And when you get a tattoo for the first time. . . on human skin, have someone to supervise you".

Sensible knowledge allows for relationships between aesthetics, emotions, and affectivity. It focuses on the problematic nature of intangible knowledge that is difficult to interpret, as each practitioner has unique and unquantifiable life experiences (Gherardi \& Strati, 2014). This is presented in the speech reproduced below:

Such a thing is vision. . You have to look at the details, up close and such. And I've always been very fond of looking at the details. . See what you're doing. You have to practice your hand; in this case, your touch, right? You have to have your hand. . firm. . You only get it with experience. (Ian, 2019)

Aesthetic categories are part of the usual language of practitioners. These categories manifest themselves intertwined with the artifacts of tattooing, outlining the aesthetic experience of subjects. This experience is interspersed with the invention, reproduction, and transformation of the practice, thus being inherent to the specific organizational life. This process constitutes both the aesthetic judgment, allowing practitioners to sustain the practices socially, and the construction of the bond between practitioners and between these and their practice. It takes place through the dynamics of production, reproduction, and transformation of practices while they are performed (Gherardi, 2013).

The interconnected knowledge of everyday tattooing practices influences the action of tattoo artists and the use of artifacts in the organization within the pathos of sensible knowledge and aesthetic judgment, in the sense that it connects practitioners to their practice and allows for activation of aesthetic knowledge during manipulation. The findings in the field allow us to say that the practice of tattooing consists of six types of knowledge: (a) creation and/or reproduction of the design; (b) doings and sayings related to each practice (tattoo style, skin type, and application site); (c) manipulation of artifacts; (d) technique (line, shadow, pigment application, and biosafety); (e) body movement (firmness of hands); ( $f$ ) activation of the human senses (sensible knowledge). Figure 1 expresses the interaction between practices, knowings, and artifacts in the construction of tattooing in daily work. 


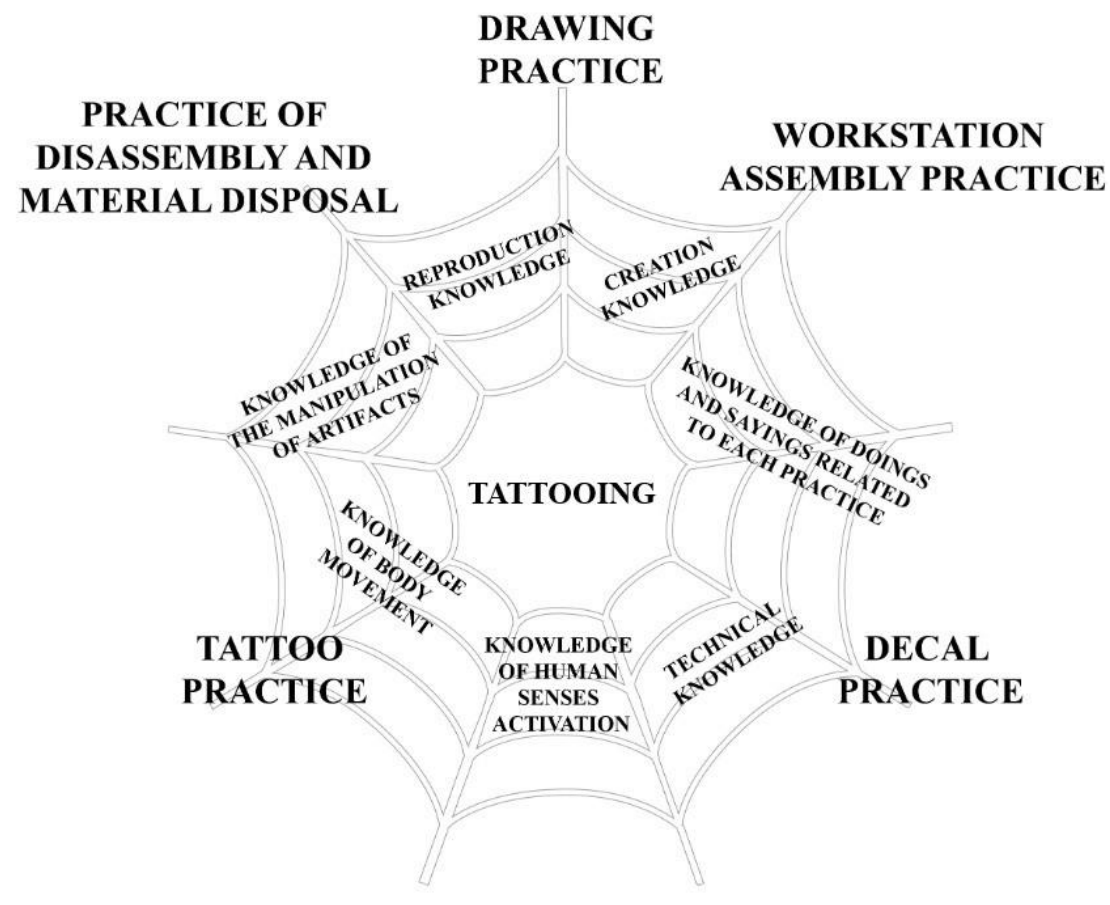

Figure 1. Construction of knowledge in tattoo work

Source: Prepared by the authors

\section{Final considerations: skin texture, paints, and practices}

This study analyzed how and what knowledge constitutes the daily work of tattooing in light of the organizational aesthetic approach. The results revealed that this knowledge comes from the activation of sensible knowledge, referring to the manipulation of artifacts (paper, needles,

pigments, tattoo machines, among other objects and materials) that act as prostheses (subject-structure) in the tattoo artist's hand and support their professional practice. The use of these artifacts is taught and learned in the process itself, reflecting the ability to use the body as a source of sensible knowledge. The interactions that support the knowing and doing in the practice of tattooing come from the manifestations of sensory faculties, from artifacts, and from the aesthetic judgment of practitioners about organizational life and their knowledge. Various representations, images, comparisons, metaphors, and symbols permeate the construction and interpretation of this social practice. This finding can be extended to other professions in which knowledge, artifacts, and sensible knowledge are coproduced during work routines as well, either through communication of sensible experiences by practitioners or through the observation and experience of different situations in which practice is performed. 
As it is a matter of taste, understanding the construction of knowledge of practice involves the sensitivity concerning the practitioner's actions, revealed in four aesthetic categories: the beautiful, which arouses the feeling of admiration for a well-done practice; the picturesque, which deals with unusual or bizarre landscapes as well as with the description of something that provokes emotions (fear, trembling, nervousness, and malaise), emphasizing the distinction between the aesthetic experience and its evocation process (the experience of tattooing the skin); the ugly, which refers to everything that should not be done, such as poorly formulated tattoos and unpleasant occurrences in the daily lives of organizations; and the agogical, which refers to the ordering and rhythm of activities regarding the progress of the practice, the sequencing of steps, the movements, and the organization of time (discovering shortcuts of the practice).

As for its implications, by shedding light on the knowledge of tattooing as a result of either an aesthetic judgment or the construction of taste and sensible knowledge, this study advances in the literature on organizational learning. It recognizes aesthetics as a form of access to and apprehension of certain practical knowledge arising from daily work, which is difficult to access, observe, measure, and represent since it is hidden and sometimes linguistically indescribable. This analysis became possible by proposing, as an alternative to the logical-rational understanding of the organizational context, the aesthetic dimension. The study brought to the focus of organizational studies the importance of this dimension in the daily life of the organization, paying attention to perceptive faculties and work routines that affect, within the scope of individual sensitivity, people who work in organizations.

Paying attention to the pathos of the sensible and making use of empathic knowledge to study the aesthetics of organizations, the present research contributes to a qualitative approach by observing the sociomateriality of organizational life. This investigation showed that, in the practice of tattooing, practicing, feeling, and knowing how to do are intertwined in a being-in-use as an integral part of a web of practices and knowledge, activated in the course of the intentional action of organizational actors.

In the practical field, the findings contribute to the understanding of the work in so-called common or outsider professions. Training in these professions does not necessarily occur through formal means of teaching; thus, they are intimately dependent on sensible knowledge and sharing of experiences among practitioners. By providing information, this study supports workers in the development of their activities and in the improvement of different knowings and ways of working. Moreover, by addressing the knowledge that constitutes the daily work of tattooing in light of the organizational aesthetic approach, the findings advance the limits of this professional category. The results expose the organizational reality experienced by craft, creative, and artistic workers and confirm the importance of combining knowledge, practice, aesthetics, and sociomateriality to understand their daily work, as their practice is immersed in idiosyncrasies.

The limitations of this study were those inherent to studies based in practices, considering the impossibility of interactions and nonobjective elements to be expressed in their entirety through oral and written language (Gherardi, 2006). Access to the field proved to be a research challenge, requiring, at times, a certain insistence from the researcher to enter the environments. In addition, we highlight the difficulty of accessing secondary data that would provide a portrait of the current status of the professional category in Brazil, as a consequence of the limited number of entities. 
We suggest that future studies deepen the question inserted in the present research regarding the knowledge produced in daily work between the different actors that make up the network of organizational practices in the context of professions such as tattooing, which are sometimes considered marginal according to social standards. Similar studies should be carry out vith a view to understand the construction of knowledge in other types of work and culture, that is, in other organizational forms. Also noteworthy is the possibility of developing discussions on the aesthetic categories present in the daily life of people in organizations due to the need to deepen the reflection on organizational aesthetics.

\section{References}

Adams, J. (2012). Cleaning up the dirty work: Professionalization and the management of stigma in the cosmetic surgery and tattoo industries. Deviant Behavior, 33(149), 149-167. doi:10.1080/01639625.2010.548297

Antonello, C. S. (2011). Contextos do saber: Aprendizagem informal. In C. S. Antonello, \& A. S. Godoy (Eds.), Aprendizagem Organizacional no Brasil (pp. 139-159). Porto Alegre, RS: Bookman.

Antonello, C. S., \& Azevedo, D. (2011). Aprendizagem organizacional: Explorando o terreno das teorias culturais e das teorias baseadas em práticas. In C. S. Antonello, \& A. S. Godoy (Eds.), Aprendizagem Organizacional no Brasil (pp. 89-113). Porto Alegre, RS: Bookman.

Arruda, J. R., Moraes, J. P., Colling, T., \& Goldoni, A. G. (2017, outubro). Carreira desviante: Prostitutas e a sua relação com o núcleo de estudos da prostituição (NEP). Artigo apresentado na 13a Semana Científica do Unilasalle, Canoas, RS.

Batista, A. S., \& Codo, W. (2018). Trabalho sujo e estigma. Cuidadores da morte nos cemitérios. Revista de Estudios Sociales, 63, 72-83. doi:10.7440/res63.2018.06

Becker, H. S. (2008). Outsiders: Estudos de sociologia do desvio. Rio de Janeiro, RJ: Jorge Zahar.

Bitencourt, B. M. (2015). Saberes do trabalho dos agentes aeroportuários à luz da noção de Knowing-in-practice (Tese de Doutorado). Universidade Federal do Rio Grande do Sul, Porto Alegre, RS. Recuperado de https://bit.ly/3fhqQ4E

Brewer, J. (2000). Ethnography. Buckingham: Open University Press.

Brock, H. (2014). A aprendizagem nas práticas dos técnicos de enfermagem de um Centro de Material e Esterilização à luz da estética organizacional (Dissertação de Mestrado). Universidade Federal do Rio Grande do Sul, Porto Alegre, RS. Recuperado de https://bit.ly/3oPxTVI

Caeiro, M., Neto, A. C., \& Guimaraes, L. V. M. (2016). A construção de sentido para o "trabalho sujo": Trajetórias de vida de faxineiras. Anais do Encontro Nacional de Estudos Organizacionais, Belo Horizonte, MG. Recuperado de https://bit.ly/3ujfktU

Camillis, P. K. (2016). Organizando com barro: A bioconstrução como prática de cooperação (Tese de Doutorado). Universidade Federal do Rio Grande do Sul, Porto Alegre, RS. Recuperado de https://bit.ly/3vmUM4K 
Cardoso, P. S., Silva. T., \& Zimath, S. C. (2017). Todo mundo olha, quase ninguém vê: A percepção de trabalhadores operacionais com relação à invisibilidade social de seus trabalhos. Cadernos Brasileiros de Terapia Ocupacional, 25(4), 701-711. doi:10.4322/2526-8910.ctoA00846

Carrieri, A. P., Souza, E. M., \& Aguiar, A. R. C. (2015). Trabalho, violência e sexualidade: Estudo de lesbicas, travestis e transexuais. RAC, 18(1), 78-96. doi:10.1590/S1415-65552014000100006

Chiesa, C. D., Gois, P. H., De Luca, G., \& Cavedon, N. R. (2015). "Tramando arames, pedras e fios": Espaço e estigma no trabalho de um artista. Ciências Sociais Unisinos, 5(1), 32-4. doi:10.4013/csu.2015.51.1.04

Corradi, G., Gherardi S., \& Verzelloni L. (2008). Ten good reasons for assuming a 'practice lens' in organization studies. Anais do 3o OLKC Conference (pp. 1-37), Copenhagen.

Costa, F. B. (2008). Moisés e Nilce: Retratos biográficos de dois garis: um estudo de psicologia social a partir de observação participante e entrevistas (Tese de Doutorado). Universidade de São Paulo, São Paulo, SP. Recuperado de https://bit.ly/3hQtakC

Davel, E., Cavedon, N. R., \& Fischer, T. (2012). A vitalidade artesanal da gestão contemporânea. Revista Interdisciplinar de Gestão Social, 1(3), 13-21. doi:10.9771/23172428rigs.v1i3.10065

DeLuca, G. (2015). "Você só tatua?": A trajetória profissional no campo da tatuagem (Dissertação de Mestrado). Universidade Federal do Rio Grande do Sul, Porto Alegre, RS. Recuperado de https://bit.ly/3flaVLM

DeLuca, G., \& Rocha, S. O. (2016). Inked careers: Tattooing professional paths. BAR, 13(4). doi:10.1590/1807-7692bar2016160081

Dyvik, S. L., \& Welland, J. (2018). War ink: Sense-making and curating war through military tattoos. International Political Sociology, 2(4), 346-361. doi:10.1093/ips/oly028

Ferrazza, D. S. (2015). Os saberes e as práticas de trabalho: Um estudo do processo de aprendizagem dos profissionais cinegrafistas em uma emissora de televisão de Porto Alegre (Dissertação de Mestrado). Universidade Federal do Rio Grande do Sul, Porto Alegre, RS. Recuperado de https://bit.ly/34jITSB

Ferreira, T. A. (2018). À flor da pele: Experiência estética em uma feira livre de Vitoria/ES (Dissertação de Mestrado). Universidade Federal do Espirito Santo, Vitória, ES. Recuperado de https://bit.ly/3wAlHKy

Ferreira, V. S. (2012). Das belas-artes à arte de tatuar: Dinâmicas recentes no mundo português da tatuagem. In M. I. M. Almeida, \& J. M. Pais (Orgs.), Criatividade \& profissionalização: Jovens, subjectividades e horizontes profissionais (pp. 55-99). Rio de Janeiro, RJ: Zahar.

Figueiredo, M. D., \& Cavedon, N. R. (2015). Transmissão do conhecimento prático como intencionalidade incorporada: Etnografia numa doceria artesanal. RAC, 19(3), 336-354. doi:10.1590/1982-7849rac20151796

Flores-Pereira, M. T., \& Cavedon, N. R. (2009). Os bastidores de um estudo etnográfico: Trilhando os caminhos teórico-empíricos para desvendar as culturas organizacionais de uma livraria de shopping center. EBAPE, 7(1), 152-168. doi:10.1590/S1679-39512009000100011 
French, M. T., Mortensen, K., \& Timming, A. R. (2018). Are tattoos associated with employment and wage discrimination? Analyzing the relationships between body art and labor market outcomes. Human Relations, 1(26), 962-987. doi:10.1177/0018726718782597

Gallon, S., Bitencourt, B. M., Viana, D. D., \& Antonello, C. S. (2016). Formas de aprendizagem e saberes no trabalho de manicures. Revista Pensamento Contemporâneo em Administração, 10(1), 96-112. doi:10.12712/rpca.v10i1.655

Gallon, S., Camillis, P., Bitencourt, B., \& Pauli, J. (2020). Saberes do trabalho de bombeiros envolvidos em um evento crítico à luz da teoria da estética organizacional. Anais do 440 Encontro da Associação Nacional dos Programas de Pós-Graduação em Administração, Rio de Janeiro, RJ.

Gherardi, S. (2000). Practice-based theorizing on learning and knowing in organizations. Organization, 7(2), 211-223. doi:10.1177/135050840072001

Gherardi, S. (2006). Organizational knowledge: The texture of workplace learning. Oxford: Blackwell.

Gherardi, S. (2009). Introduction: The critical power of the 'practice lens'. Management Learning, 40(2), 115-128. doi:10.1177/1350507608101225

Gherardi, S. (2011). Organizational learning: The sociology of practice. In M. Easterby-Smith, \& M. Lyles (Eds.), Handbook of organizational learning, knowledge management (2a ed., pp. 43-65). Oxford: Blackwell.

Gherardi, S. (2012). How to conduct a practice-based study: Problems and methods. Massachusetts: Elgar.

Gherardi, S. (2013). Prática? É uma questão de gosto! Revista Interdisciplinar de Gestão Social, 2(1), 107-124. doi:10.9771/23172428rigs.v2i1.10047

Gherardi, S. (2014). Conhecimento situado e ação situada: O que os estudos baseados em prática prometem? In S. Gherardi, \& A. Strati (Orgs.), Administração e aprendizagem na prática (pp. 3-17). Rio de Janeiro, RJ: Elsevier.

Gherardi, S. (2017). Sociomateriality in posthumanist practice theory. In A. Hui, T. Schatzki, \& E. Shove (Eds.), The nexus of practices: Connections, constellations, practitioners (pp. 38-51). Londres: Routledge.

Gherardi, S., \& Miele, F. (2018). Knowledge management from a social perspective: The contribution of practice-based studies. In J. Syed, P. A. Murray, D. Hislop, \& Y. Mouzughi (Eds.), The Palgrave handbook of knowledge management (pp. 151-176). Cham: Palgrave Macmillan.

Gherardi, S., \& Nicolini, D. (2001). The sociological foundations of organizational learning. In M. Dierkes, A. Berthoin, J. Child, \& I. Nonaka (Orgs.), The handbook of organizational learning and knowledge (pp. 35-60). Oxford: Oxford University Press.

Gherardi, S., \& Strati, A. (2014). Administração e aprendizagem na prática. Rio de Janeiro, RJ: Elsevier. 
Glynn, S. J. (2017). You think it, they ink it: Interactive service encounters in the tattoo industry (Tese de Doutorado). Universidade de Vanderbilt, Nashville. Recuperado de https://bit.ly/3fNbGmy

Gómez, G. S. R. (2017). Construção de identidade e trajetória social desviante: Um estudo empírico com guardadores de carro em Pelotas, RS. Primeiros Estudos, 8, 89-104. doi:10.11606/issn.2237-2423.v0i8p89-104

Jagannathan, S., Selvaraj, P., \& Joseph, J. (2016). The funeralesque as the experience of workers at the margins of international business: Seven Indian narratives. Critical Perspectives on International Business, 12(3), 282-305. doi:10.1108/cpoib-05-2015-0023

Kosut, M. (2014). The artification of tattoo: Transformations within a cultural field. Cultural Sociology, 8(2), 142-158. doi:10.1177/1749975513494877

Leader, K. J. (2015). Stories on the skin: Tattoo culture at a South Florida university. Arts and Humanities in Higher Education, 14(4), 426-446. doi:10.1177/1474022215575162

Lopes, L. L. S., Ipiranga, A. S. R., \& Silva, J. J. J. (2017). Compreensão empática e as possíveis contribuições para a pesquisa nos estudos organizacionais: Reflexões a partir da experiência do lado estético das organizações. EBAPE, 15(4), 831-845. doi:10.1590/1679-395155010

Lopes, L. L. S., Souza, E. M., \& Ipiranga, A. S. R. (2014). Desvelando as categorias estéticas na organização de um pequeno restaurante. Revista Interdisciplinar de Gestão Social, 3(1), 207-222. doi:10.9771/23172428rigs.v3i1.9005

Machado, R. S. (2018). ARS (TIFEX): Articulações na formação e no fazer de tatuadores (Dissertação de Mestrado). Universidade Federal de Juiz de Fora, Juiz de Fora, MG. Recuperado de https://bit.ly/3fNbGmy

Magno, L., Dourado, I., \& Silva, L. A. V. (2018). Estigma e resistência entre travestis e mulheres transexuais em Salvador, Bahia, Brasil. Cadernos de Saúde Pública, 34(5). doi:10.1590/0102$311 \times 00135917$

Mavin, S., \& Grandy, G. (2013). Doing gender well and differently in dirty work: The case of exotic dancing. Gender, Work \& Organization, 20(3), 232-251. doi:10.1111/j.1468-

0432.2011.00567.x

Merriam, S. B. (1998). Qualitative research and case study applications in education. San Francisco: Jossey-Bass.

Monteiro, D. F. B., Pereira, V. F., Oliveira, L. L., Lima, O. P., \& Carrieri, A. P. (2017). Trabalho sujo com a morte: O estigma e a identidade no ofício de coveiro. Revista Interdisciplinar de Gestão Social, 6(1), 77-98. doi:10.21714/2317-2428/

Naves, F., \& Reis, Y. (2017). Diseñando la resistencia: Contrahegemonía y expresiones estéticas del movimiento agroecológico en Brasil. EBAPE, 15(2), 309-325. doi:10.1590/1679-395163488

Nicolini, D. (2012). Practice theory, work, and organization: An introduction. Oxford: Oxford University Press.

Oliveira, L. Y. M. (2012). Arquitetura dos processos de aprendizagem à luz da teoria da estética organizacional: Etnografia em uma revenda de móveis planejados (Dissertação de Mestrado). 
Universidade Federal do Rio Grande do Sul, Porto Alegre, RS. Recuperado de https://bit.ly/3wvKHCJ

Orlikowski, W. J. (2002). Knowing-in-practice: Enacting a collective capability in distributed organizing. Organization Science, 13(3), 249-273. doi:10.1287/orsc.13.3.249.2776

Orlikowski, W. J. (2007). Socialmaterial practices: Exploring technology at work. Organization Studies, 28(9), 1435-1448. doi:10.1177/0170840607081138

Ostaszkiewicz, J., O'Connell, B., \& Dunning, T. (2016). 'We just do the dirty work': Dealing with incontinence, courtesy stigma and the low occupational status of carework in long-term aged care facilities. Journal of Clinical Nursing, 25(17-18), 2528-2541. doi:10.1111/jocn.13292

Patterson, M. (2018). Tattoo: Marketplace icon. Consumption Markets \& Culture, 21(6), 582-589. doi:10.1080/10253866.2017.1334280

Prá, R. (2019). Práticas e saberes de profissionais que trabalham com dados à luz da teoria atorrede (Dissertação de Mestrado). Universidade Federal do Rio Grande do Sul, Porto Alegre, RS. Recuperado de https://bit.ly/3bRHJRs

Queiroz, D. T., Vall, J., Souza, A. M. A., \& Vieira, N. F. C. (2007). Observação participante na pesquisa qualitativa: Conceitos e aplicações na área da saúde. Revista Enfermagem UERJ, 15(2), 276-283.

Rees, M. (2016). From outsider to established-explaining the current popularity and acceptability of tattooing. Historical Social Research/Historische Sozialforschung, 41(3), 157-174, 2016.

Riessman, C. K. (2008). Narrative methods for the human sciences. Los Angeles: Sage.

Rodrigues, D. S. (2012). Saberes sociais e luta de classes: Um estudo a partir da colônia de pescadores artesanais (Tese de Doutorado). Universidade Federal do Pará, Belém, PA. Recuperado de https://bit.ly/2Tg9cWq

Rose, M. (2007). O saber no trabalho: A valorização da inteligência do trabalhador. São Paulo, SP: Senac.

Rudnicki, D., Schäfer, G., \& Silva, J. C. (2017). As máculas da prisão: Estigma e discriminação das agentes penitenciárias. Revista Direito GV, 13(2), 608-627. doi:10.1590/2317-6172201724

Schiavo, S. R. (2010). As práticas de trabalho e o processo de aprendizagem de trabalhadores da construção civil à luz da estética organizacional (Dissertação de Mestrado). Universidade Federal do Rio Grande do Sul, Porto Alegre, RS. Recuperado de https://bit.ly/3fHk8E5

Schwartz, Y. (2001). Trabalho e Educação. [Entrevista concedida a H. Santos, \& D. M. Cunha]. Presença Pedagógica, 7(38), 5-17.

Scott, M. (2017). Hipster capitalism in the age of austerity? Polanyi meets Bourdieu's new petite bourgeoisie. Cultural Sociology, 11(1), 60-76. doi:10.1177/1749975516681226

Silva, A. N., \& Saraiva, L. A. S. (2014). Contornando o estigma: Uma análise dos estúdios de tatuagens em Belo Horizonte. TPA-Teoria e Prática em Administração, 4(1), 123-155. Recuperado de https://bit.ly/2SkLQhP 
Silva, F. L. D. L., Souza, P. C. Z. D., Araújo, A. J. D. S., \& Pinto, F. D. M. (2016). Stigmatization and risks in the work of necrotomists. Psicologia: Teoria e Pesquisa, 32(1), 133-141. doi:10.1590/0102-37722016012302133141

Simpson, R., \& Pullen, A. (2018). 'Cool' meanings: Tattoo artists, body work and organizational 'bodyscape'. Work, Employment and Society, 32(1), 169-185. doi:10.1177/0950017017741239

Soares, L. C. (2015). O processo de aprendizagem do cozinhar em João Pessoa/PB à luz das práticas sociais e da estética organizacional (Dissertação de Mestrado). Universidade Federal da Paraíba, João Pessoa, PB. Recuperado de https://bit.ly/3hOvQPS

Söllinger, M. E., \& Antonello, C. S. (2020). Palidez estética na Universidade: Inquietações acerca da aprendizagem da docência. Revista Brasileira de Estudos Organizacionais, 7(1), 185-230. doi:10.21583/2447-4851.rbeo.2020.v7n1.375

Souza, F. L. G. (2015). Da margem à moda: O processo de desmarginalização da tatuagem - um olhar a partir da prática da contemporânea da tatuagem na cidade de Três Lagoas - MS. Trilhas da História, 5(9), 126-141. Recuperado de https://bit.ly/3fIOA9G

Strati, A. (1992). Aesthetic underst anding of organizational life. Academy of Management Review, 17(3), 568-581. doi:10.5465/amr.1992.4282009

Strati, A. (1996). Organizations viewed through the lens of aesthetics. Organization, 3(2), 209-218. doi: $10.1177 / 135050849632004$

Strati, A. (1999a). Organization and aesthetics. Londres: Sage.

Strati, A. (1999b). Putting people in the picture: Art and aesthetics in photography and in understanding organizationa life. Organization Studies, 20(7), 53-69. doi: 10.1177/017084060002000704

Strati, A. (2000). The aesthetic approach in organization studies. In S. Linstead, \& H. Höpfl (Eds.), The aesthetics of organization (pp. 13-34). Londres: Sage.

Strati, A. (2003). Knowing in practice: Aesthetic understanding and tacit knowledge. In S. Gherardi, \& D. Nicolini (Orgs.), Knowing in organizations: A practice-based approach (pp. 53-75). Nova lorque: M.E. Sharpe.

Strati, A. (2007a). Sensible knowledge and practice-based learning. Management learning, 38(1), 61-77. doi:10.1177/1350507607073023

Strati, A. (2007b). Organização e estética. Rio de Janeiro, RJ: Editora FGV.

Strati, A. (2008a). "Dietro le quinte": La ricerca qualitativa sulla dimensione estetica dell' organizzazione. In R. Cipriani (Ed.), L'analisi qualitativa: Teorie, metodi, applicazioni (pp. 73-88). Roma: Armando.

Strati, A. (2008b). Aesthetics of organization. In S. Clegg, \& J. R. Bailey (Eds.), International encyclopedia of organization studies (pp. 38-41). Los Angeles: Sage.

Strati, A. (2014). Conhecimento sensível e aprendizagem baseada na prática. In S. Gherardi, \& A. Strati (Eds.), Administração e aprendizagem na prática (pp. 61-82). Rio de Janeiro, RJ: Elsevier. 
Titchen, A., \& Horsfall, D. (2011). Creative research landscapes and gardens reviewing options and opportunities. In J. Higgs, A. Titchen, D. Horsfall, \& D. Bridges (Eds.), Creative spaces for qualitative researching: Living research (pp. 35-44). Rotterdam: Sense.

Tracy, S. J. A. (2004). The construction of correctional officers: Layers of emotionality behind bars. Qualitative Inquiry, 10(4), 509-533. doi:10.1177/1077800403259716

Wright, W. M. I. (2017). Blessed the tattoo: Reflections on spirituality \& popular devotions. $A$ Journal of Christian Spirituality, 17(1), 80-105. doi:10.1353/scs.2017.0005

Zestcott, C. A., Tompkins, T. L., Williams, M. K., Livesay, K., \& Chan, K. L. (2018). What do you think about ink? An examination of implicit and explicit attitudes toward tattooed individuals. The Journal of Social Psychology, 158(1), 7-22. doi:10.1080/00224545.2017.1297286

\section{Financing}

The authors did not receive financial support for the research, authorship, or publication of this article.

\section{Authorship \\ Rúbia Goi Becker}

Master's degree by Graduate Program in Administration by Federal University of Santa Maria (UFSM).

E-mail: rubiagoibecker@gmail.com

ORCID: https://orcid.org/0000-0001-6774-6294

\section{Simone Alves Pacheco de Campos}

$\mathrm{PhD}$ in Administration by Federal University of Rio Grande do Sul (UFRGS). Professor and researcher at the Department of Administrative Sciences and Graduate Program in Administration at the Federal University of Santa Maria.

E-mail: simone.campos@ufsm.br

ORCID: https://orcid.org/0000-0001-9627-7677

\section{Claudia Simone Antonello}

PhD in Administration by Federal University of Rio Grande do Sul (UFRGS). Professor and researcher at the Graduate Program in Administration and School of Administration at the Federal University of Rio Grande do Sul.

E-mail: claudia.antonello@ufrgs.br

ORCID: https://orcid.org/0000-0001-9654-5125

\section{Conflict of interests}

The authors have stated that there is no conflict of interest. 


\section{Authors' contributions}

FIrst author: conceptualization (equal), data curation (lead), formal analysis (lead), investigation (lead), methodology (lead), project administration (lead), resources (equal), supervision (lead), validation (equal), visualization (equal), writing - original draft (equal), writing-review and editing (equal).

Second author: conceptualization (equal), data curation (supporting), formal analysis (supporting), investigation (supporting), methodology (supporting), project administration (supporting), resources (equal), supervision (supporting), validation (equal), visualization (equal), writing original draft (equal), writing-review and editing (equal).

Third author: conceptualization (equal), data curation (supporting), formal analysis (supporting), investigation (supporting), methodology (supporting), project administration (supporting), resources (equal), supervision (supporting), validation (equal), visualization (equal), writing original draft (equal), writing-review and editing (equal).

\section{Plagiarism check}

O\&S submit all documents approved for publication to the plagiarism check, using specific tools.

\section{Data availability}

O\&S encourages data sharing. However, in compliance with ethical principles, it does not demand the disclosure of any means of identifying research participants, preserving fully their privacy. The practice of open data seeks to ensure the transparency of the research results, without requiring the identity of research participants.

O\&S is signatory to DORA (Declaration on Research Assessment) and to COPE (Committee on Publication Ethics). 